\title{
FACTORS AFFECTING INDIVIDUAL CUSTOMERACCEPTANCE OF MOBILE BANKING SERVICES IN VIETNAM
}

\author{
Ai Huu Tran \\ Dao Mai Thi Hong \\ Van Hien University, Ho Chi Minh, Vietnam \\ Thanh Vinh Bui \\ Vietinbank, Tay Tien Giang Branch, Vietnam
}

The study determines the influence of transaction costs, favorable conditions, hedonic motivation, security awareness, social influence and beliefs, expected performance and trust as significant factors affecting the intention to use mobile banking services. The results of the study show that the statistically significant relations of these factors, from the highest to the lowest, are as follows: favorable conditions, hedonic motivation, the value of transaction

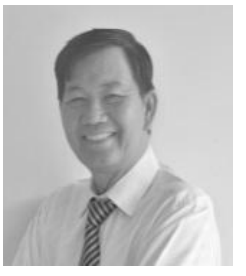

\section{Ai Tran Huu}

$\mathrm{PhD}$, Lecturer in Economics Department, Van Hien University, Ho Chi Minh City, Vietnam.

Research interest - agricultural market, support for small and medium enterprises, organic food market, eco-economy, environmental issues of economic development and social responsibility, theory of market's function, modern trends of development, corporative management; multinational corporation in service's production: organization, strategic management, global competitive resources.

Published more than 70 articles on international journals and 40 national articles, participated 12 scientific conferences.

E-mail: aith@vhu.edu.vn

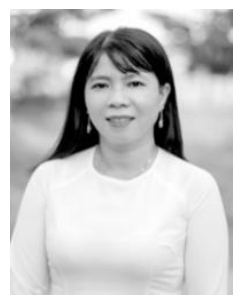

\section{Dao Mai Thi Hong}

MBA, Lecturer at the Faculty of Economics, Van Hien University, Ho Chi Minh City, Vietnam.

Research interests: consumer behavior; innovative product markets; finance.

Published more than 10 papers in International journals.

E-mail: daomth@vhu.edu.vn

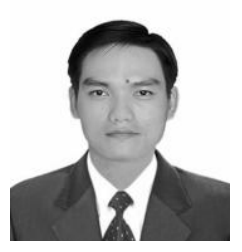

\section{Thanh Bui Vinh}

MBA, Director Viettin Bank, Tay Tien Giang Branch Research interests: SMEs functioning and government support, consumer behavior, innovative products markets and finances.

Published more than 10 papers in International journals.

E-mail: vinhthanhdbk@gmail.com 


\section{FACTORS AFFECTING INDIVIDUAL CUSTOMERACCEPTANCE}

costs, security awareness, social influence and beliefs, and finally, the expected performance.

Keywords: social influence and beliefs; hedonic motivation; security awareness; favorable conditions; cost value; mobile banking services; Vietnam.

\section{Introduction}

Mobile banking, including account management via mobile devices, has significantly changed its operations during the recent years. Today it is helping banks in reducing costs and increasing efficiency for customers. Mobile devices, smartphones especially, are the most promising means to reach out to customers due to the ability to provide services anytime, anywhere, and due to high penetration rate and development potential overall (Dineshwar et al., 2013).

Many studies have also provided other factors affecting the intention to use mobile banking, such as perceptions of service advantages (Brown et al., 2003); customer compatibility, trust, social norms (Mortimer et al., 2010); demographics (Yu, 2012). In addition, there are studies showing perceived risks, cost, and ease of use (Koening-Lewis et al., 2010); at the same time, awareness of trust (Alam, 2014) seems to not affect the intention to use mobile banking. Studies show that in different contexts, the influencing factors also differ. On the other hand, demographic variables are often considered as control ones but not considered as the moderating variables for the intention to use mobile banking services.

Until 2017, Vietnam had $4.8 \mathrm{mln}$ broadband Internet subscribers, about $31 \mathrm{mln}$ Internet users (thus accounting for $34 \%$ of the total population) (Lin, 2011). According to the market research carried out by IDC, Vietnam is one of the top three smartphone growth markets in the Southeast Asia with the percentage of mobile phone subscribers using smartphones reaching $40 \%$ in 2015. As it was then forecasted, in 2018, the rate of smartphone usage in Vietnam would increase to about $70 \%$, and by 2021 the number of smartphone subscribers in the country will increase 3 times as compared to 2015. Therefore, the trend of using mobile banking is an indispensable part of this larger trend.

\section{Literature review}

Electronic banking (e-banking), also known as Internet banking, is understood as the use of electronic and telecommunication networks to provide banking services to customers (Aduda \& Kingoo, 2012). E-banking has greatly improved banks' efficiency and significantly changed the operations of retail banks, increasing numerous customer benefits in the first place.

According to (Shaikh \& Karjaluoto, 2015), mobile banking has been first implemented in the late 1990s, when the German Paybox company, in cooperation with Deutsche Bank, launched the very first service of this kind. Initially, it was deployed and tested primarily in European countries, such as Germany, Spain, Sweden, Austria and then also in the USA. For many years, ATM networks, telephone banking and then also Internet banking have been providing solid distribution channels, however, the latest distribution channel of mobile banking created by retail banks has already demonstrated a great influence on the market (Shaikh et al., 2015). Mobile banking can be divided into two main components: first, stock transactions and the use of other related services via mobile phones; secondly, mobile 
banking (in the narrow sense), includes account management with the use of mobile devices (Tran \& Corner, 2016).

Mobile banking service allows users receive information about their account balances via SMS. Mobile phones that support WAP radio application protocols, phones using GPRS general packet radio service support various types of banking services such as transferring money between accounts, trading securities and confirming securities receive payments directly via telephone (Tran \& Corner, 2016). Mobile banking means conducting customer transactions with the bank using mobile phones or similar digital devices (Al-Jabri \& Sohail, 2012).

The benefits of mobile banking from the perspective of banks are as follows: increasing customer satisfaction with the bank; enhanced competitiveness within the banking industry; adaptation to the requirements of the target customer group; increased volume of products and services provided to customers; lower distribution costs; stronger brand reputation; increased ability to reach out to new customers and keep already loyal customers at the same time (Zhou, 2012).

Previous research has shown that the adoption and use of technology is a necessity for technological innovation (Al-Jabri \& Sohail, 2012). Among various models proposed previously, five theoretical models prevailed in the studies (Joshua \& Koshy, 2009), until Venkatesh \& Zhang (2010) proposed the theory on consolidation of technology adoption and use (UTAUT), with development through evaluation, arrangement and synthesis of eight key theories and models, including: reasonable action theory (TRA); technology adoption model (TAM) (Davis et al., 1989); motivation theory (MM) (Davis et al., 1989); the theory of planned behavior (TPB); combination of planned behavior theory and the technology of acceptance theory (C-TPB-TAM); the model of using computers (MPCU); the theory of innovation diffusion (IDT) and the theory of social awareness (SCT). TAM model is a simple, both practical and theoretical model. It is an adaptation of TRA from the field of psychology of information systems (Baptista \& Oliveira, 2017). It appears to be the most widely accepted within the research on information systems (Hanafizadeh et al., 2014).

Social influence and beliefs are defined as the extent to which an individual is aware that people are important as the technology is important (Mortimer et al., 2015). This factor is similar to the Subjective Standard defined in the TAM2 Technology Acceptance Model, an extension of TAM. Mortimer et al. (2016) demonstrated that learning motivation and social influence have a positive impact on the intentions of behavior, while favorable conditions do not affect the use of online learning portals. In this study, social influence is defined as the impact of other people on the feelings of individuals with a strong impact on their use of mobile banking (Venkatesh et al., 2012).

Favorable conditions are defined as the extent to which an individual believes that necessary resources are needed to support the use of the system (Venkatesh et al., 2012). In this study, it is defined as the degree to which an individual believes the resources they have to support the use of mobile banking service system (Venkatesh et al., 2012). Mahfuz et al. (2016) show that favorable conditions have a positive effect on the intentions for behavior, but most studies show that favorable conditions do not affect the intention to use mobile banking, for example the research by Alawan et al. (2016), Aboelmaged and Gebba (2013), Baptista and Oliveira (2015), Ahmed et al. (2017).

Hedonism is defined as the joy of using technology in its own way and perceiving some usefulness or effectiveness from it (Davis, et al., 1989). Research in the field of 


\section{FACTORS AFFECTING INDIVIDUAL CUSTOMERACCEPTANCE}

technology has shown that hedonic motivation, understood as perceived enjoyment, has a direct impact on the adoption and use of technology (for example, Shaikh et al., 2015). Venkatesh et al. (2012) added the sense of joy as a factor influencing consumer adoption and further use of technology.

Cost value is understood as the balance of consumer awareness between the benefits of applications and the cost of using those (Venkatesh et al., 2012). One difference between individual consumers and organizations when they use the service is that they themselves have to spend the costs, which can affect their usage behavior. For example, there is research evidence that using SMS instead of the Internet banking in China is predetermined by lower service fees (Yu, 2012).

Security awareness is the degree of trust with which an organization will handle all transactions securely, and keep personal information confidential (Roca et al., 2012). Privacy and security have a significant influence on customer attitudes towards mobile banking (Hernandez et al., 2008). The importance of privacy and security for the acceptance of online banking technology is being studied all the time. The main concerns of customers in relation to bank security are monetary risk $(\mathrm{Yu}, 2012)$ and also the possibility of taking advantage of customer information by service providers.

User security awareness ensures that users have their confidence in the e-banking services (Lin, 2011). Personal financial information can be intercepted and used for fraudulent purposes, therefore, online investment involves greater commercial security concerns than conventional trade. Users need to feel secure when making financial transactions, and this is still one of the main barriers to e-commerce growth (Afshan \& Sharif, 2016).

Expected performance is defined as the degree to which an individual believes that using the system will enable him/her to achieve certain goals (Davis et al., 1992). Expected performance is driven by perceived usefulness, relative advantage, external motivation and job fit. The background theory here is derived from usefulness perception (as in technology acceptance theory), available motivation (motivational model), suitability for work (model use of a PC), relative advantage (the theory of innovation dissemination) and expected results (the theory of social awareness).

Intention in mobile banking is the willingness of a person to accept service (David et al., 1989). Venkatesh et al. (2012) and Venkatest \& Zang (2010) both have demonstrated behavioral intentions significantly influence the use of technologies.

The behavior of customers using mobile banking is the frequency of use over a period of time or it can be seen the number of transactions. The ultimate goal of banks is to attract customers to use the service rather than those with the intention to receive the service. Some studies have examined the relationship between the intent to use and the actual use.

\section{Model and hypothesis of this research}

Based on the general analysis of the study on the factors affecting individual customers when accepting mobile banking services, the author group chooses the approach and the research model as per the unified theory and using UTAUT and Venkatest \& Zang (2010) technology because of the similarities in the field of research. The model consists of 6 independent variables: Influence and social trust (SIB), Favorable conditions (AC), $\mathrm{MH}$ (hedonic dynamics), Transaction cost value (VTC), Security awareness (SA), Expected 
efficiency (EE). The observation variable is both an independent variable and a dependent variable: Intention to use mobile banking (IUMB); while the dependent variable is: Behavior of using mobile banking (BUMB).

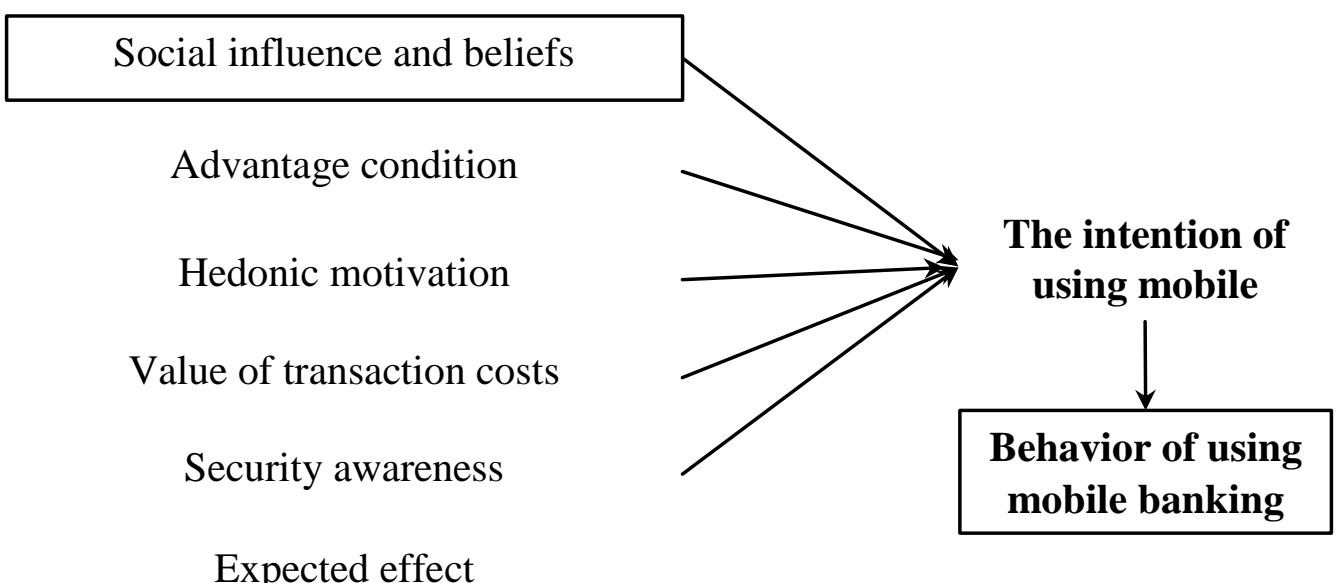

Figure 1 - The proposed research model (made by co-authors)

The hypotheses as per this research model include:

- Hypothesis H1: Social influence has a positive effect the intention of using mobile banking;

- Hypothesis H2: Favorable conditions have a positive effect the intention of using mobile banking;

- Hypothesis H3: Hedonic motivation has a positive effect on the intention of using mobile banking;

- Hypothesis H4: Cost value has a positive effect the intention of using mobile banking;

- Hypothesis H5: Expected efficiency has a positive effect on the intention of using mobile banking;

- Hypothesis H6: Security awareness has a positive effect on the intention of using mobile banking;

- Hypothesis H7: The intention of using mobile banking has a positive effect on the behavior of using mobile banking.

\section{Research Methods}

Quantitative research within this study is based on different methods used to quantify measure, reflect and interpret the relationships among the factors under consideration. The quantitative research process is conducted through two steps: (1) Preliminary quantitative research and (2) Official quantitative research.

The people surveyed in our case have been individuals using and not using mobile banking. These are people who use mobile phones and have transactions with commercial banks in Vietnam. The sample was selected according to a convenient method based on the 
referral of one individual to another. The respondents answered questions concerning the service of the bank they were using at the time of surveying. The survey was conducted during October-December 2019.

\section{Discussion of the obtained results}

The survey was conducted through direct delivery of paper questionnaires or via emailing to the respondents. 350 questionnaires were given out, totaling 308 questionnaires were then returned, thus, the response rate was $88 \%$. 17 questionnaires were removed due to inadequate information. Therefore, at the end, 291 questionnaires were used for the analysis, with the final response rate reaching $94.48 \%$.

Table 1 - Summary of the descriptive statistics

(Source: Summary of the replies provided by the authors)

\begin{tabular}{|c|l|c|c|}
\hline \multicolumn{2}{|c|}{ Parameters } & Number of people & Weight (\%) \\
\hline \multirow{3}{*}{ Time of using } & Less than 1 year & 49 & 16,84 \\
mobile banking & From 1 to less than 2 years & 64 & 21,99 \\
& From 2 to less than 3 years & 91 & 31,27 \\
& For 3 years and more & 87 & 29,90 \\
\hline \multirow{5}{*}{ Number of } & 1 bank & 181 & 62,20 \\
banks & 2 banks & 64 & 21,99 \\
& 3 banks & 27 & 9,28 \\
& More than 3 banks & 19 & 6,53 \\
\hline \multirow{5}{*}{$\begin{array}{c}\text { Use of mobile } \\
\text { banking services }\end{array}$} & Transfers & 69 & 23,71 \\
& Payments & 88 & 30,24 \\
& Saving deposits for 1-12 & 73 & 23,37 \\
& Saving deposits for more & & 11,00 \\
\hline \multirow{2}{*}{ Used or not at all } & Han 12 months & 49 & 79,73 \\
& Are not using & 232 & 20,27 \\
\hline
\end{tabular}

Evaluation of scales: First, the scales will be preliminarily evaluated through two methods: Cronbach's Alpha reliability coefficient and the exploratory factor analysis (EFA). Next, the scales are verified by means of confirmatory factor analysis (CFA) method.

\section{Exploratory Factor Analysis (EFA)}

The results of this part of our analysis show that 34 observed variables in the 8 components of the factors affecting the customers using mobile banking also maintained the same 7 factors with 34 observed variables. KMO coefficient $=0.755$, so EFA is consistent with the data, and Chi-quare statistics of Bertlett's test is reaching 7939.590 with the significance level of 0.00 . Therefore, the observed variables are correlated with each other in terms of the overall scope. The variance extracted by 73.008 indicates that the 7 factors 
extracted were explained by $73.008 \%$ variation of the data $(>50 \%)$, at a separate value coefficient of 1.033. Therefore, the scale drawn is acceptable.

Table 2 - Summary on reliability and total variance of the extracting scales

(Source: Calculated by the authors)

\begin{tabular}{|c|l|c|c|c|c|}
\hline $\mathrm{N}_{0}$ & \multicolumn{1}{|c|}{ Scales } & $\begin{array}{c}\text { Number of } \\
\text { items }\end{array}$ & $\begin{array}{c}\text { Reliability } \\
\text { coefficient }\end{array}$ & $\begin{array}{c}\text { Total variance } \\
\text { extracted }\end{array}$ & Conclusion \\
\hline 1 & Social influence and beliefs & 4 & 0,714 & $4,592 \%$ & \\
\cline { 1 - 5 } 2 & Advantage condition & 4 & 0,913 & $7,77 \%$ & \\
\cline { 1 - 5 } 3 & Hedonic motivation & 4 & 0,944 & $10,224 \%$ & \multirow{2}{*}{ Qualified } \\
\cline { 1 - 5 } 4 & Value of transaction costs & 4 & 0,862 & $7,039 \%$ & \\
\cline { 1 - 5 } 5 & Security awareness & 5 & 0,886 & $27,262 \%$ & \\
\cline { 1 - 5 } 6 & Expected effect & 4 & 0,821 & $4,87 \%$ & \\
\hline 7 & The intention of using mobile banking & 4 & 0,798 & $6,399 \%$ & \\
\hline 8 & Behavior of using mobile banking & 4 & 0,739 & $3,612 \%$ & \\
\hline
\end{tabular}

\section{Confirmatory factor analysis (CFA)}

In terms of general suitability, the factor analysis confirms that this model has a square Chi statistical value of 365.412 with 221 degrees of freedom $(p=0,000)$. The relative square root of the degrees of freedom CMIN/df is $1.653(<0.2)$. Other indicators are as follows: GLI $=0.907(>0.9)$, TLI $=0.956(>0.9)$, CFI $=0.965(>0.9)$ and RMSEA $=0.047(<0.08)$. Therefore, this model is suitable for our data.

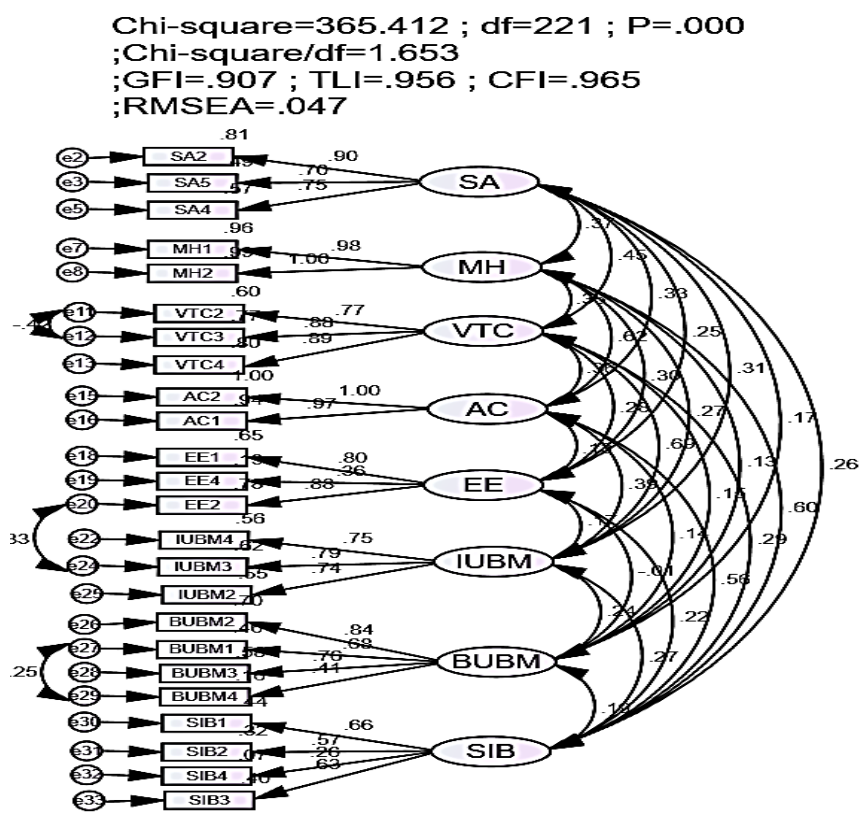

Figure 2 - CFA analysis results

(Source: Calculated by the authors)

This also allows us to draw statements about the unidirectionality of the observed 
variables. Regarding the convergence value, the standard weights of the scales are $>0.5$ and have the statistical significance of $\mathrm{p}<0.5$. Therefore, the scales achieve the convergent values.

\section{Structural equation modeling (SEM)}

In our research model, there are 8 research concepts, including 6 independent ones.The results show that the linear structural model has the square root with the statistical value of 3785492 with 228 degrees of freedom $(\mathrm{p}=0,000)$. The relative square root of the degrees of freedom CMIN / df is $1.660(<0.2)$. Other indicators are as follows: GLI $=0.904(>0.9)$, TLI $=0.96(>0.9)$, CFI $=0.964(>0.9)$ and RMSEA $=0.045(<0.08)$. Therefore, this model is compatible with our market data. This means we can be accepting the hypotheses H1, H2, $\mathrm{H} 3, \mathrm{H} 4, \mathrm{H} 5 \mathrm{H} 6$ and $\mathrm{H} 7$.

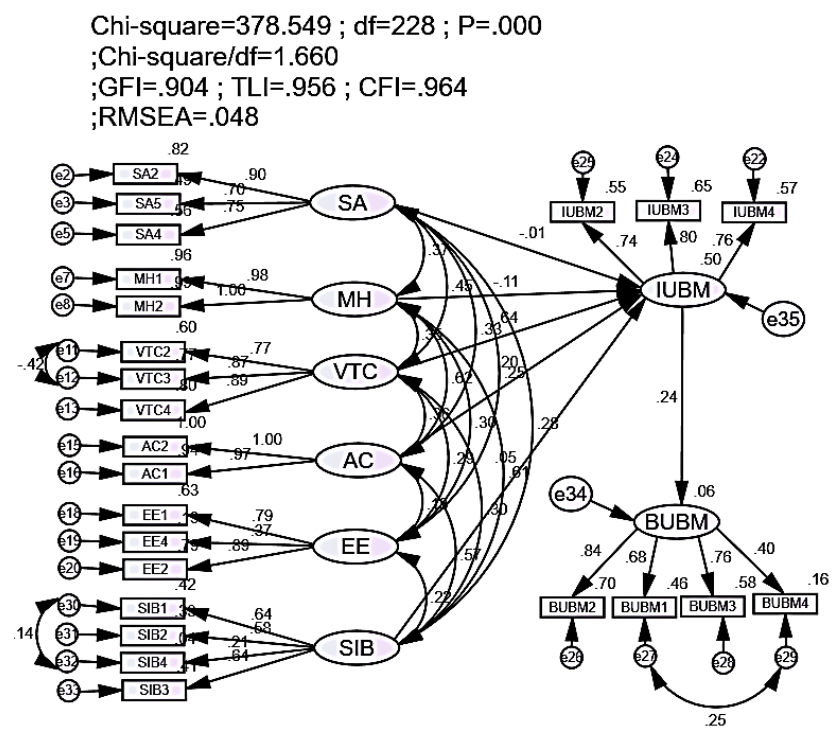

Figure 3 - Results of a calibrated structural model (via SEM).

(Source: Calculated and designed by the authors)

\section{Testing the reliability of estimates by means of bootstrap}

The bootstrap method is usually used to test the model estimates, with the pattern repeat being $\mathrm{N}=1000$. The estimation results for 1000 samples averaged together with the deviations are presented in Tab. 8.

CR has a very small absolute value, thus, it can be stated that the deviation is very small, while it is also not statistically significant at the $95 \%$ confidence level. Thus, we can conclude that the model estimates can be trusted. 
Table 4 - Results of bootstrap estimations, $\mathrm{N}=1000$

(Source: Calculated by the authors)

\begin{tabular}{|c|c|c|c|c|c|c|c|c|c|}
\hline \multicolumn{3}{|c|}{ Parameter } & Estimate & SE & SE-SE & Mean & Bias & $\begin{array}{l}\text { SE- } \\
\text { Bias }\end{array}$ & $\mathrm{CR}$ \\
\hline IUBM & $\begin{array}{l}<-- \\
-\end{array}$ & SA & 0.107 & 0.063 & 0.001 & -0.006 & 0.001 & 0.002 & 0.5 \\
\hline IUBM & $\begin{array}{l}<-- \\
-\end{array}$ & $\mathrm{MH}$ & 0.082 & 0.055 & 0.001 & -0.081 & 0.001 & 0.002 & 0.5 \\
\hline IUBM & $\begin{array}{l}<- \\
-\end{array}$ & VTC & 0.645 & 0.094 & 0.002 & 0.643 & -0.001 & 0.003 & -0.3 \\
\hline IUBM & $\begin{array}{l}<-- \\
- \\
\end{array}$ & $\mathrm{AC}$ & 0.159 & 0.063 & 0.001 & 0.152 & -0.008 & 0.002 & -4 \\
\hline IUBM & $\begin{array}{l}<- \\
- \\
\end{array}$ & SIB & 0.064 & 0.147 & 0.003 & 0.073 & 0.009 & 0.005 & 1.8 \\
\hline BUBM & $\begin{array}{l}<-- \\
- \\
\end{array}$ & IUBM & 0.254 & 0.090 & 0.002 & 0.245 & -0.009 & 0.003 & -3 \\
\hline
\end{tabular}

\section{Discussion of the results and directions for further research}

Mobile banking, including account management via mobile devices, has significantly changed banking operations. It helps banks with reducing costs and increasing efficiency for customers. Mobile devices, smartphones and tablets especially, are the most promising means to reach out to customers (Shaikh et al., 2015).

With mobile technologies, banks are now able to offer a much wider variety of services to their customers such as payment transfers while traveling, receiving online updates on stock prices and even conducting stock transactions while on the go.

Trust is very important for any business relationship, it plays an important role in ecommerce, as it tends to reduce uncertainty ( $\mathrm{Yu}, 2012)$. In the field of technology, trust represents a catalyst for the relationship between the buyer and the seller (Yu, 2012).Trust in mobile bankingcan affect the intention to use and customer behavior overall. Without trust, there is no acceptance or further use of any service (Zhou, 2012). Lack of customer trust is one of the reasons why customers do not accept and use mobile banking, despite all the numerous benefits behind mobile banking (Alalwan et al., 2013).

Among those who are using mobile banking, most people choose it because they feel the benefits that mobile banking brings such as: being able to pay bills, perform transactions 24/7, obtain other, mostly consulting services. Still, $28.5 \%$ of mobile banking users are choosing it for objective reasons, not because of their feelings. They are aiming to receive benefits that this service brings in.

This also indirectly shows that the influence of people around plays an important role in this regard. The statistical results show that there are many reasons for customers not to be using mobile banking. Many customers are still worried about security, technical errors when making transactions, complicated registration processes and procedures. Besides, there might be some other reasons such as customers having no need in mobile banking as such. Another interesting reason why customers do not feel any need in such services is because mobile banking is not being properly introduced to them by the bank, thus, customers do not understand the utility of these services. 


\section{FACTORS AFFECTING INDIVIDUAL CUSTOMERACCEPTANCE}

Security is the strongest factor affecting the intention to use mobile banking. Its influence is higher than that of other main factors in the original model.

However, there are also some studies demonstrating that security and privacy issues have a relatively low impact on the use of online technology (including electronic banking) such as Shaikh (2015). Many customers feel dissatisfied when using mobile banking services of some banks because of the situations that often occur when they make transactions such as system errors, network congestion due to too many operations happening at the same time. This has been well demonstrated by Mahfuz et al. (2016); Baptista \& Oliveira (2016); Afshan \& Sharif (2016).

The key limitation of this study is that it has only covered urban areas in the North, Central and South regions of Vietnam. Rural population is not represented in our sample as such. In other words, the sample is not highly representative.

Direction for future research: The authors have obviously not studied all the factors that directly affect the behavior of banks' customers using mobile banking. Therefore, adding other factors can be one of promising directions in the research on the same topic.

\section{References:}

Aboelmaged, M. \& Gebba, T. R. (2013). Mobile banking adoption: an examination of technology acceptance model and theory of planned behavior. International Journal of Business Research and Development, 2(1).

Aduda, J. \& Kingoo, N. (2012). The relationship between electronic banking and financial performance among commercial banks in Kenya. Journal of Finance and Investment analysis, 1(3), 99-118.

Afshan, S. \& Sharif, A. (2016). Acceptance of mobile banking framework in Pakistan. Telematics and Informatics, 33(2), 370-387.

Ahmed, Z., Kader, A., Rashid, H. U. \& Nurunnabi, M. (2017). User Perception \& Mobile Banking Adoption: An Integrated Ttf-Utaut Model. Journal of Internet Banking and Commerce, 22(3), $1-19$.

Al-Jabri, I. \& Sohail, M. S. (2012). Mobile banking adoption: Application of diffusion of innovation theory. Available at: https://www.semanticscholar.org/paper/Mobile-BankingAdoption\%3A-Application-of-Diffusion-Al-Jabri-Sohail/04276265e077947093d6dc1 f772a19c7f98cfa12

Alalwan, A. A., Dwivedi, Y. K., Rana, N. P. \& Williams, M. D. (2016). Consumer adoption of mobile banking in Jordan: examining the role of usefulness, ease of use, perceived risk and self-efficacy. Journal of Enterprise Information Management, 29(1), 118-139.

Alam, M. M. (2014). Factors Affecting Consumers Adoption of Mobile Banking in Bangladesh: An Empirical Study. TNI Journal of Engineering and Technology, 31-37.

Baptista, G. \& Oliveira, T. (2017). Why so serious? Gamification impact in the acceptance of mobile banking services. Internet Research, 27(1), 118-139.

Brown, I., Cajee, Z., Davies, D. \& Stroebel, S. (2003). Cell phone banking: predictors of adoption in South African exploratory study. International journal of information management, 23(5), 381-394.

Davis, F. D., Bagozzi, R. P. \& Warshaw, P. R. (1989). User acceptance of computer technology: a comparison of two theoretical models. Management science, 35(8), 982-1003. 
Dineshwar, R. \& Steven, M. (2013, February). An investigation on mobile banking adoption and usage: A case study of Mauritius. In Proceedings of 3rd Asia-Pacific Business Research Conference, 25-26.

Joshua, A. J. \& Koshy, M. P. (2009). Usage patterns of electronic banking services by urban educated customers: Glimpses from India. The Journal of Internet Banking \& Commerce. Available at: http://www.icommercecentral.com/open-access/usage-patterns-of-electronic-banking-servicesby-urban-educated-customers-glimpses-from-india.php?aid=38138.

Koenig-Lewis, N., Palmer, A. \& Moll, A. (2010). Predicting young consumers' take up of mobile banking services. International journal of bank marketing, 28(5), 410-432.

Hanafizadeh, P., Behboudi, M., Koshksaray, A. A. \& Tabar, M. J. S. (2014). Mobile banking adoption by Iranian bank clients. Telematics and Informatics, 31(1), 62-78.

Lin, H. F. (2011). An empirical investigation of mobile banking adoption: The effect of innovation attributes and knowledge-based trust. International journal of information management, 31(3), 252-260.

Mortimer, G., Neale, L., Hasan, S. F. E. \& Dunphy, B. (2015). Investigating the factors influencing the adoption of m-banking: a cross cultural study. International Journal of Bank Marketing, $33(4), 545-570$.

Mahfuz, M. A., Khanam, L. \& Hu, W. (2016, September). The influence of culture on m-banking technology adoption: An integrative approach of UTAUT2 and ITM. In Management of Engineering and Technology (PICMET), 2016 Portland International Conference: 824-835.

Shaikh, A. A. \& Karjaluoto, H. (2015). Mobile banking adoption: A literature review. Telematics and Informatics, 32(1), 129-142.

Tran, H. T. T. \& Corner, J. (2016). The impact of communication channels on mobile banking adoption. International Journal of Bank Marketing, 34(1), 78-109.

Venkatesh, V., Thong, J. Y. \& Xu, X. (2012). Consumer acceptance and use of information technology extending the unified theory of acceptance and use of technology. MIS quarterly, 157-178.

Venkatesh, V. \& Zhang, X. (2010). Unified theory of acceptance \& use of technology: US vs. China. Journal of Global Information Technology Management, 13(1), 5-27.

Yu, C. S. (2012). Factors affecting individuals to adopt mobile banking: Empirical evidence for the UTAUT model. Journal of Electronic Commerce Research, 13(2), 104.

Zhou, T. (2012). Understanding user's initial trust in mobile banking: An elaboration likelihood perspective. Computers in Human Behavior, 28(4), 1518-1525.

Paper submitted

Paper accepted for publishing

Paper published online
11 May 2020

23 July 2020

31 July 2020 